\title{
Palynomorphs from the Cyrtograptys centrifugus graptolite zone (Early Wenlock, Silurian), Bornholm
}

\author{
MORTEN SMELROR
}

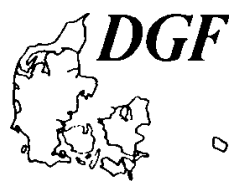

\begin{abstract}
Smelror, M.: Palynomorphs from the Cyrtograptus centrifugus graptolite zone (Early Wenlock, Silurian) on Bornholm. Bull. geol. Soc. Denmark, Vol. 39, pp. 83-89. Copenhagen, December 20th, 1991. https://doi.org/10.37570/bgsd-1991-39-02

Palynomorph assemblages recovered from the Cyrtograptus centrifugus graptolite zone on Bornholm contain moderately diverse acritarchs and prasinophycean algae, and minor chitinozoans and miospores. The generally poor preservation is due mainly to a high thermal alteration of the sediments. The indentified Early Wenlock (Sheinwoodian) palynomorph assemblages are closely related to those described from contemporaneous deposits elsewhere in northwest Europe and U.S.S.R., and they are characterized by common representatives of the genera Leiosphaeridia, Diexallophasis, Oppilatala, Salo-pidium and Michystridium. The palynomorph assemblages herein described are similar to the marine floras from the open marine deep water deposits of the Wenlock carbonate shelf of the Welsh Borderland and Midlands of England as described by Dorning and Bell (1987) (the Saliopidium granuliferum Assemblage). The presence of Domasia elongata and Domasia trispinosa, together with ?Deunffia sp. confirm that the Early Wenlock deposits on Bornholm are coeval with the Deunffia - Domasia facies proper as defined by Cramer $(1970,1971,1971 a)$.
\end{abstract}

Morten Smelror, Institutt for Kontinentalsokkelunders $\emptyset$ kelser og Petroleumsteknologi A/S (IKU), N.7034 Trondheim, Norge. November 4 th, 1990.

\section{Introduction}

The Silurian strata on Bornholm crop out in faulted terrain and are only exposed along the Løså and Øleå rivulets in the southern part of the island (Figure 1).

The oldest Silurian succession comprises a 135 $m$ thick unit of transgressive dark-grey mudstone of Llandovery age, which has come to be called the "Rastrites"-shale. These beds are conformably overlain by $25 \mathrm{~m}$ - thick unit of dark grey mudstone of earliest Wenlock age, i.e. the "Cyrtograptus-shale”. The late Wenlock strata, which represents the youngest Silurian deposits on Bornholm, was probably deposited in a deeper basin than the Llandovery sediments (Gravesen and Bjerreskov, 1984).

A review of the Paleozoic strata on Bornholm has been published by Poulsen (1966), and the stratigraphy of the Llandovery Series at Øleå has been reviewed by Bjerreskov (1971). Bjerreskov (1975) gave a complete review af the Silurian, including information from the Bavnegård well. In this important contribution Bjerreskov described the graptolite faunas from both the Llandovery and Wenlock Series and further presented a detailed biostratigraphic zonation. The present study was initiated to investigate the palynological potential of these well-dated Silurian deposits.

\section{Palynomorph assemblages and thermal alteration}

A total of twenty-nine samples from both Llandovery and Wenlock deposits were perpared and examined for organic-walled microfossils. Unfortunately, the sediments have been subjected to significant degrees of thermal alterations, and most samples yielded only poorly preserved specimens. The acritarchs are generally greyish and black (grading to dark brown) in colour, and frequently crushed and corroded. According to the Thermal Alteration Index of Staplin (1969, 1977), these sediments have been heated to above $150^{\circ} \mathrm{C}$, as the estimated TAI values fall between \pm 3.7 and \pm 4.0. Data from studies of the Cambrian Alum Shale on Bornholm indicate a thermal maturation corresponding to vitrinite reflectance values around $2 \%$ Ro (Buchardt \& Nielsen, 1985), and a corresponding conclusion 


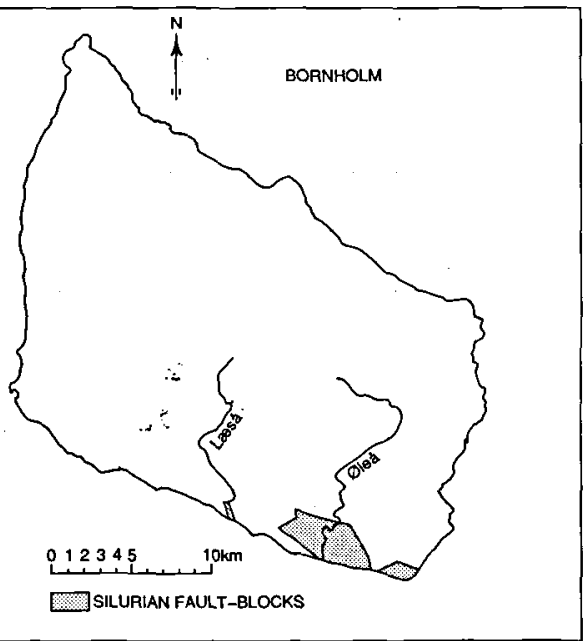

Fig. 1. Sketch-map showing the location of the rivulets Læsa and Øleå on Bornholm and the position of the Silurian fault blocks. (From Bjerreskov 1975).

can be reached from the conodont coulor alteration index of approximately 5. Although, extensive magmatic activity is known to have taken place during the Carboniferous and Permian periods in Scania north of Bornholm (Klingspor 1976) and in the Oslo Region (Larsen et al. 1981), Buchardt and Nielsen (1985) argued that the high termal alteration of the Lower Paleozoic succession is due to geothermal impact from deep burial rather than from magmatic heating. They further suggestd that the major burial event leading to the thermal diagenesis of the Lower Paleozoic rocks on Bornholm is related to the later phases of the Caledonian orogeny.

The only indentifiable assemblages we recovered in our material were found in samples from the deposits representing the Cyrograptus centrifugs graptolite zone. These were collected from a exposure near the outlet of Øleå, about $200 \mathrm{~m}$ north of Slusegård (Figure 2). A total of 23 acritarchs species, 4 species of prasinophycean algae, 2 chitinozoan species and 2 taxa of miospores/ sporelike microfossils were identified (see species list below):

\section{Acritarchs:}

Ammonidium cf. A. ludlovensis (Lister) Dorning 1981.
Ammonidium microcladum (Downie) Lister 1970.

?Deunffia sp.

Diexallophasis denticulata (Stockmans et Williére) Loeblich 1970.

Diexallophasis cf. sanpetrensis (Cramer) Dorning 1981.

Diexallophasis simplex Wicander er Wood 1981.

Domasia elongata Downie 1960.

Domasia trispinosa Downie 1960.

Eupoikilofusa sp. I

Leiofusa tumida Downie 1959.

Lophosphaeridium papillatum (Staplin) Downie 1963.

Micrhystridium stellatum group Deflandre 1945.

Micrhystridium uncinatum (Downie) Martin 1965.

Multiplicisphaeridium arbusculum Dorning 1981.

Multiplicisphaeridium cladum Downie 1963.

Oppilatala ramusculosa (Deflandre) Dorning 1981.

Rhacobranchion mala (Cramer) Dorning 1981.

Salopidium granuliferum (Downie) Dorning 1981.

Schismatosphaeridium sp.

Tunisphaeridium tentaculiferum (Martin) Cramer 1970.

Veryhachium trispinosum group (Eisenack)

Deunff ex Downie 1959.

Visbysphaera dilatispinosa (Downie) Lister 1970.

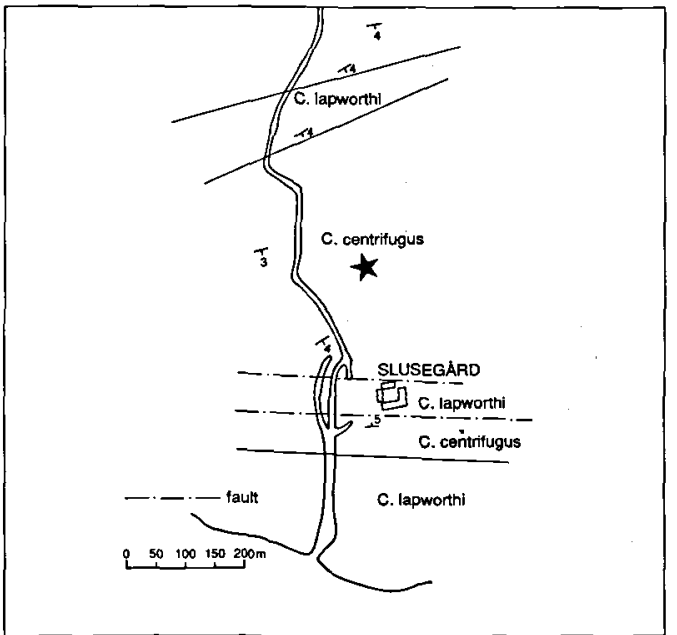

Fig. 2. Map of the outcropping Silurian strata at the rivulet $\emptyset$ leå near the farm Slusegård (After Bjerreskov 1975). The location of the present studied samples is marked by*. 
Fig. 3. Comparisons of the palynomorph assemblages found in the earliest Wenlock on Bornholm and assemblages reported from contemporaneous deposits on Gotland and Ringerike and in England, Belgium, U.S.S.R. and Austria. Data from: 1) Cramer et al. 1979, Gray et al. 1974, Laufeld 1974; 2) Smelror 1987, 1987a, unpubl.; 3) Dorning 1981, 1981a, 1981b, 1982, 1983; Dorning \& Bell 1987. Downie 1959, 1963, 1984; Hill 1974; Mabillard \& Aldridge 1985; Barron 1989; 4) Martin 1968, 1974; Verniers 1981; 5) Sheshegova 1975; Kirjanov 1978; 6) Priewalder 1987.

\begin{tabular}{|c|c|c|c|c|c|c|}
\hline & $\begin{array}{c}1 \\
\text { Gotland } \\
\text { Sweden }\end{array}$ & $\begin{array}{c}2 \\
\text { Ringerike } \\
\text { Norway }\end{array}$ & $\begin{array}{c}3 \\
\text { Div. Loc. } \\
\text { England }\end{array}$ & $\begin{array}{c}\quad 4 \\
\text { Div. Loc. } \\
\text { Belgium }\end{array}$ & $\begin{array}{c}\quad 5 \\
\text { Div. Loc. } \\
\text { U.S.S.R }\end{array}$ & $\begin{array}{c}6 \\
\text { Karnische } \\
\text { alpen Austria }\end{array}$ \\
\hline Ammonidium microcladum & $\mathrm{x}$ & $\mathbf{x}$ & $\mathrm{x}$ & & $\mathbf{x}$ & $x$ \\
\hline Diexallophasis denticulata & $\mathbf{x}$ & $\mathbf{x}$ & $\mathbf{x}$ & $\mathbf{x}$ & $\mathrm{x}$ & $\mathrm{x}$ \\
\hline Diexallophasis simplex & $\mathbf{x}$ & $\mathbf{x}$ & $\mathbf{x}$ & $\mathrm{x}$ & $\mathbf{x}$ & $x$ \\
\hline Deunffia spp. & $\mathbf{x}$ & & $\mathbf{x}$ & $\mathbf{x}$ & $\mathbf{x}$ & $\mathbf{x}$ \\
\hline Domasia elongata & $\mathrm{x}$ & $\mathbf{x}$ & $\mathbf{x}$ & $x$ & $\mathbf{x}$ & \\
\hline Domasia trispinosa & $\mathbf{x}$ & $\mathbf{x}$ & $\mathbf{x}$ & $\mathbf{x}$ & $\mathrm{x}$ & $\mathrm{x}$ \\
\hline Leiofusa tumida & $\mathbf{x}$ & $\mathbf{x}$ & $\mathbf{x}$ & $\mathbf{x}$ & $\mathbf{x}$ & $\mathrm{x}$ \\
\hline Lophosphaeridium papillatum & & $\mathbf{x}$ & $\mathbf{x}$ & $\mathbf{x}$ & $\mathbf{x}$ & $\mathbf{x}$ \\
\hline Micrhystridium stellatum & $\mathbf{x}$ & & $\mathbf{x}$ & $\mathbf{x}$ & & $\mathrm{x}$ \\
\hline Micrhystridium uncinatum & & & $\mathbf{x}$ & $\mathrm{x}$ & & \\
\hline Multiplicisphaeridium arbusculum & $\mathbf{x}$ & & $\mathbf{x}$ & $\mathrm{x}$ & & \\
\hline Multiplicisphaeridium cladum & & & $\mathbf{x}$ & & & $?$ \\
\hline Oppilatata ramusculosa & $\mathbf{x}$ & $\mathbf{x}$ & $\mathbf{x}$ & $\mathrm{x}$ & $\mathbf{x}$ & $\mathrm{x}$ \\
\hline Rhacobranchion mala & & & $\mathbf{x}$ & $\mathbf{x}$ & & \\
\hline Salopidium granuliferum & & $\mathbf{x}$ & $\mathbf{x}$ & $\mathbf{x}$ & $\mathbf{x}$ & $\mathbf{x}$ \\
\hline Tunisphaeridium tentaculiferum & $\mathrm{x}$ & $\mathbf{x}$ & $\mathrm{x}$ & $\mathrm{x}$ & $\mathbf{x}$ & $\mathbf{x}$ \\
\hline Veryhachium trispinosum & $\mathbf{x}$ & $\mathbf{x}$ & $\mathbf{x}$ & $\mathbf{x}$ & $\mathbf{x}$ & $\mathbf{x}$ \\
\hline Visbysphaera dilatispinosa & $\mathbf{x}$ & $\mathbf{x}$ & $\mathrm{x}$ & $\mathrm{x}$ & $\mathbf{x}$ & \\
\hline Visbysphaera oligofurcata & $\mathbf{x}$ & $\mathrm{x}$ & $\mathrm{x}$ & & $\mathrm{x}$ & $?$ \\
\hline Cymatiosphaera octoplana & $\mathbf{x}$ & $\mathrm{x}$ & $\mathrm{x}$ & $\mathrm{x}$ & $\mathrm{x}$ & \\
\hline Leiosphaeridia granulata & & $\mathrm{x}$ & $\mathrm{x}$ & $\mathbf{x}$ & & \\
\hline Leiosphaeridia laevigata & & $\mathbf{x}$ & $\mathrm{x}$ & $\mathbf{x}$ & $\mathrm{x}$ & \\
\hline Leiosphaeridia wenlockia & & $\mathbf{x}$ & $\mathrm{x}$ & $\mathbf{x}$ & $\mathrm{x}$ & \\
\hline Ancyrochitina ancyrea & $\mathrm{x}$ & $\mathrm{x}$ & $\mathbf{x}$ & $\mathbf{x}$ & & \\
\hline Ancyrochitina primitiva & $\mathbf{x}$ & $\mathrm{x}$ & $\mathrm{x}$ & $\mathbf{x}$ & & \\
\hline Ambitiosporites spp. & $\mathbf{x}$ & $\mathbf{x}$ & $\mathrm{x}$ & & & \\
\hline Nodospora/Tetrehedraletes spp. & $\mathbf{x}$ & $\mathbf{x}$ & $\mathbf{x}$ & & & \\
\hline No. of taxa in common: & 19 & 21 & 27 & 22 & 17 & $12(? 14)$ \\
\hline
\end{tabular}

\section{Visbysphaera oligofurcata (Eisenack) Lister 1970.}

\section{Prasinophycean algae:}

Cymatiosphaera octoplana Downie 1959.

Leiosphaeridia granulata Eisenach 1938.

Leiosphaeridia laevigata Stockmans \& Williére 1963.

Leiosphaeridia wenlockia Downie 1959.

\section{Chitinozoans:}

Ancyrochitina ancyrea Eisenack 1955. Ancyrochitina primitive Eisenack 1964.

\section{Miospores/spore-like microfossils:}

\section{Tetrahedraletes medinensis Strother \& Traverse} 1979.

Nodospora sp.

With few exceptions, the recovered species occur in low numbers or are present only in one or a few samples. The most common species are: $O p$ pilatala ramusculosa, Salopidinium granuliferum and representatives of the genera Diexallophasis, Micrhystridium ans Leiosphaeridia.

Although abundant in two samples from the middle of the $C$. centrifugus Zone, Eupoikiofusa sp. I was not observed in the samples from the lowermost and uppermost metres of the $C$. centrifugus Zone. Chitinozoans, i.e. Ancyrochitina ancyrea and $A$. primitiva were only found in the upper part of the $C$. centrifugus Zone, while the 


\begin{tabular}{|c|c|c|c|c|c|}
\hline EPOCH & \multicolumn{2}{|c|}{ AGE } & GRAPTOLITE ZONES & ACRITARCH ZONES & MIOSPORE ZONES \\
\hline \multirow{7}{*}{ Wenlock } & \multirow{3}{*}{ Homerian } & \multirow{2}{*}{ Gleedon } & Monographus ludensis & Eisenackidium wenlockensis & \multirow{2}{*}{$\begin{array}{l}\text { "E."cf. protophanus - } \\
\text { cf. s. verrucatus }\end{array}$} \\
\hline & & & Gothograptus nassa & \multirow{4}{*}{ Cymatiosphaera pavimenta } & \\
\hline & & Whitwell & Cyrtograptus lundgreni & & \multirow{6}{*}{$\begin{array}{l}\text { A. chulus var. chulus - } \\
\text { A. chulus var. nanus }\end{array}$} \\
\hline & \multirow{4}{*}{\multicolumn{2}{|c|}{ Sheinwoodian }} & $\begin{array}{l}\text { Cyrtograptus ellesae } \\
\text { Cyrtograptus linnarssoni }\end{array}$ & & \\
\hline & & & Cyntograptus rigidus & & \\
\hline & & & \begin{tabular}{|c} 
Monograptus riccartonensis \\
Cyrtograptus murchisoni
\end{tabular} & Deunffia brevispinosa & \\
\hline & & & Cyrtograptus centrifugus & Deunffia brevispinosa & \\
\hline \multirow{3}{*}{$\begin{array}{l}\text { Llandovery } \\
\text { (pars.) }\end{array}$} & \multirow{3}{*}{\multicolumn{2}{|c|}{ Telychian }} & Monoclimacis crenulata & \multirow{3}{*}{ Deuntfia monospinosa } & \\
\hline & & & Monoclimacis griestoniensis & & - ? \\
\hline & & & Monograptus crispus & & A. avitus - A. dilutus (pars.) \\
\hline
\end{tabular}

Fig. 4. Correlation of the acritarchs zones defined in the Llandovery (pars.) and Wenlock Epoch in Shropshire (Dorning \& Bell, 1987), the miospore zonation of the old Red Sandstone continent (Richardson \& McGregor, 1986) and the standard graptolite zonation.

miospore Ambitiosporites $s p$. and the spore-like palynomorph Tetrahedraletes medinensis were restricted to the lowermost sample within the zone.

\section{Regional comparisons and paleoecological aspects}

A comparison of the palynomorph assemblages found in the earliest Wenlock on Bornholm and assemblages reported from contemporaneous deposits on Gotland (Sweden), Ringerike (Norway), England, Belgium, U.S.S.R. and Austria is presented in Figure 3. All acritarchs and prasinophycean algae species (excluding those left under open nomenclature) found on Bornholm have been described from Britain. A somewhat lower number of the palynomorph taxa from Bornholm are also reported from Gotland and the Oslo Region, while only 12 (- ?14) species are common to both Bornholm and the Karnisch Alps (Austria). This latter disparity may be a result of the more comprehensive data available on Silurian palynomorphs from Britain as compared to Austria.

However, provincialism of early-middel Silurian acritarchs has been well documented by Cramer (1970, 1971, 1971a), Cramer and Diez de Cramer (1972) and Cramer and Diez (1974). These authors recognized distinctive acritarchs facies, with boundaries parallel to the Silurian paleolatitudes. The regions listed in Figure 3 fall within the Deunffia-facies, which can be identified by the presence of common Deunffia. The
Deunffia-facies generally includes a few "baltisphaerids" of the Hoegklintia digitata - H. corallina group as well as moderately common $\mathrm{Do}$ masia spp. (Cramer 1970). The Early Wenlock acritarch assemblages described from Gotland yielded among others Deunffia furcata, D. ramusculosa, D. monospinosa, Domasia rochesterensis, D. amphora, D. elongata and D. trispinosa (Cramer et al., 1979), and the poor recovery of Deunffia and Domasia in the contemporaneous Bornholm samples can probably be explained by the poor preservation of the assemblages. The representatives of both Deunffia and Domasia are small and delicate forms and are likely to have a poorer preservation potential than most larger and more thickwalled species.

The biostratigraphic distribution of acritarch in the British Silurian has been outlined in several papers, the most important ones concerning the Early Wenlock being those of Dorning (1981), Downie (1984), Mabillard and Aldridge (1985) and Dorning and Bell (1987). The acritarch zones defined within the Wenlock Series in Shropshire (England) by Doring and Bell (1987) are shown in Figure 4. The zones were not directly coeval with the standard graptolite zones, but the oldest Wenlock acritarch zones were defined from the Builderas Formation, which is known to span the C. centrifugus, C. murchisoni and the lowermost M. riceartonensis graptolite Zones (Bassett et al., 1975). The Deunffia brevispinosa Zone and the Deunffia brevifurcata Zone of Dorning and Bell (1987) are equivalent to the acritarch zones 5 and 5 a of Hill (1974), respectively. According to 


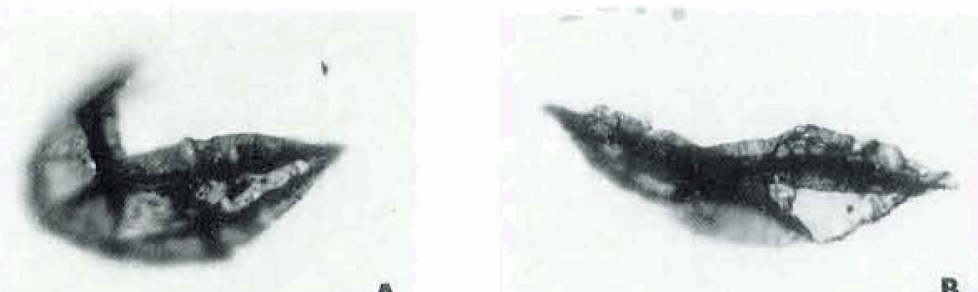

A

B.
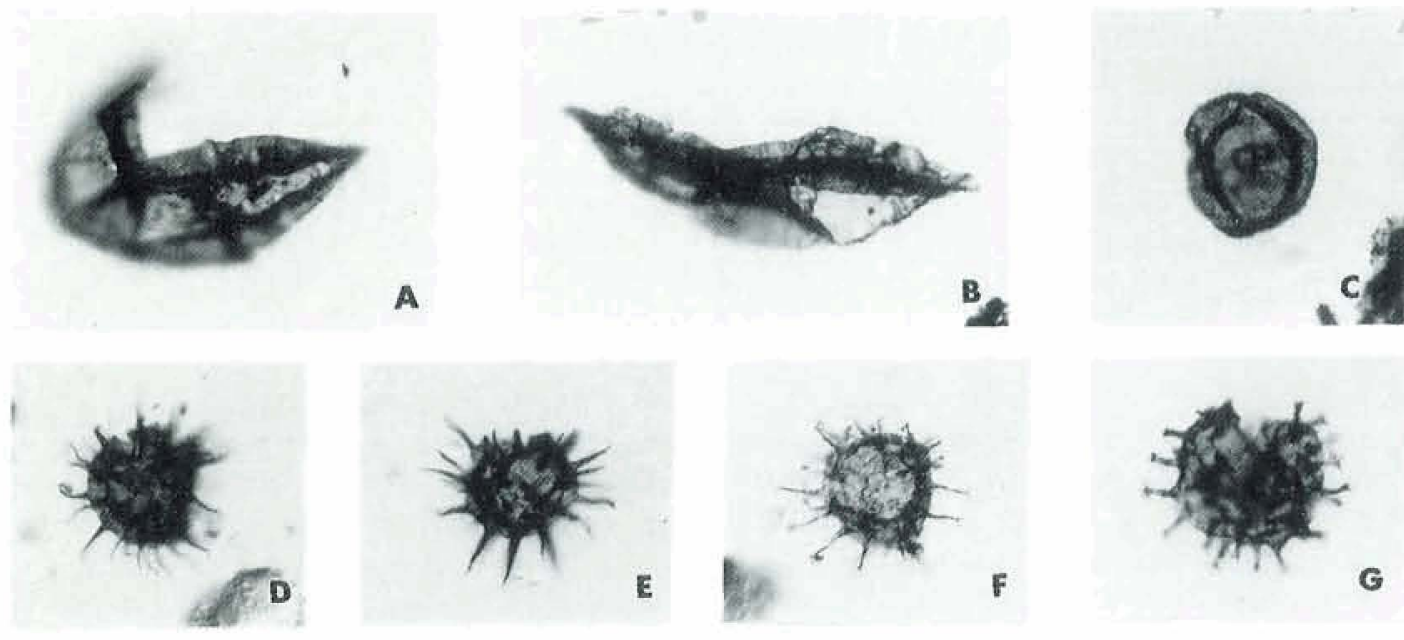

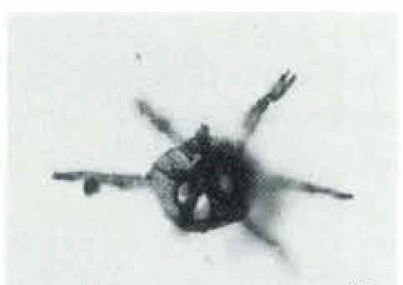

H
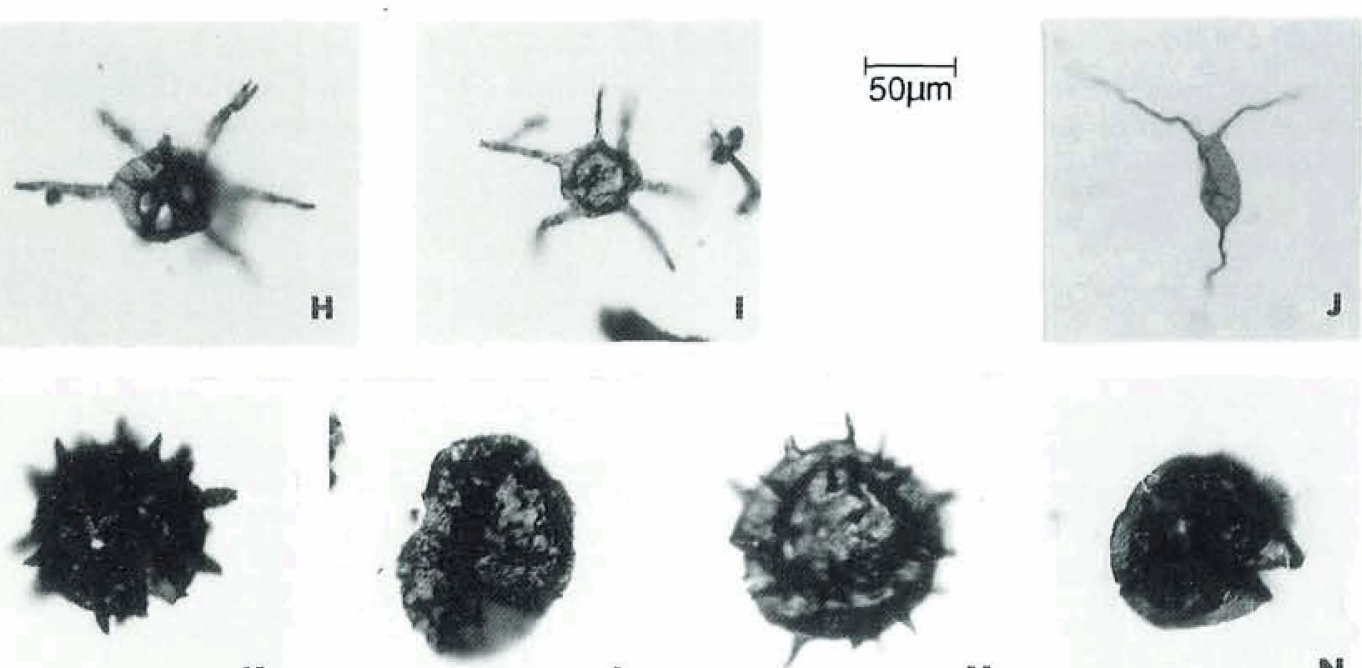

$\mathbf{K}$

\begin{abstract}
1
\end{abstract}

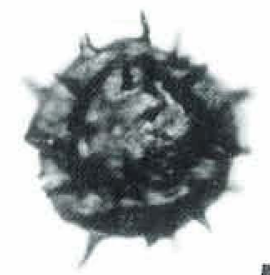

M

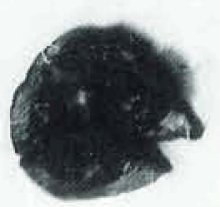

$\mathbf{N}$

Fig. 5. Palytnomorphs from the Cyrtograpus centrifugus graptolite zone on Bornholm.

A) Eupoikilofusa sp. I. Sample 9C, ref. P38/0.

B) Eupoikilofusa sp. I. Sample 9Ci, ref. N21/0.

C) Lophosphaeridium papillatum (Staplin) Downie 1963. Sample 2D, ref. $\$ 42 / 0$.

D) Micrhystridium stellatum group Deflandre 1945. Sample $6 \mathrm{C}$, ref. $M 42 / 2$.

E) Micrhystridium stellatum group Deflandre 1945. Sample 6B. ref. R40/0.

F) Ammonidium microcladum (Downie) Lister 1970. Sample 9C, ref. N39/0.

G) Ammonidium of $A$. Indlovensis (Lister) Dorning 1981. Sample $6 \mathrm{C}$, ref. N39/0.

Dorning and Bell (1987), the base of the Deunffia brevispinosa zone is synchronous with the Llandovery/Wenlock boundary. Mabillard and Aldridge (1985), however, found that the key species, Deunffia brevispinosa, D. ramusculosa and
H) Diexallophasis denticulata (Stockmans \& Williére) Loeblich 1970. Sample 2D, ref. S42/4.

I) Diexallophasis denticulata (Stockmans \& Williére) Leoblich 1970. Sample 7B, ref. O32/0.

J) Domasia elongata Downie 1960. Sample 2B, ref. P42/3.

K) Rhacobranction mala (Cramer) Darning 1981. Sample $6 \mathrm{~A}$, ref. $139 / 0$.

L) Leiosphaeridia sp. Sample 9B, ref. P51/0.

M) Salopidium granuliferum (Downie) Dorning 1981. Sample 9A, ref. G33/2.

N) Tetrahedraletes medinensis Strother \& Traverse 1979. Sample $2 B$, ref. $L 44 / 2$.

Domasia amphora first appear in the uppermost Llandovery in the Wenlock Edge area (i.e. the type Wenlock area). The boundary of the overlying Deunffia brevifurcate Zone of Dorning and Hill (1987) is recognized by the earliest appear- 
ance of Deunffia brevifurcata. As shown by Hill (1974), Dorning (1981), Mabillard and Aldridge (1985), and Dorning and Bell (1987), representatives of the genus Deunffia are sensitive biostratigraphic index taxa within the uppermost Llandovery and Early Wenlock in Britain. Because of the poorly preserved assemblages from Bornholm, it was not possible to test the stratigraphic utility of Deunffia in the Danish Silurian succession.

A zonation of Silurian and Devonian spores of the Old Red Sandstone continent and adjacent regions has recently been published by Richardson and McGregor (1986). The presence of Ambitiosporites sp. and Tetrahedraletes medinensis in the $C$. centrifugus Zone on Bornholm give no precise age indications. A general comparison with the zonation scheme of Richardson and McGregor (1986) show that the Early Wenlock deposits are correlative with the chulusnanus spore zone, which spans the latest Llandovery and Early Wenlock Epoch. The comparable Sheinwoodian spore assemblages recorded from the Steinsfjorden Formation on Ringerike in the Oslo Graben (Smelror 1987a), can also be related to this spore zone.

The potential use of Silurian palynomorphs in environmental interpretations have been advocated in the recent years by Al-ameri (1983), Dorning (1981b) and Dorning and Bell (1987). The assemblages recorded from the earliest Wenlock on Bornholm appear to be related to the Salopidium granuliferum Assemblage of Dorning and Bell (1987). According to these authors, the Salopidium granuliferum Assemblage is characterized by moderate species diversities, with 25-35 distinctive forms. Common acritarchs include Leiosphaeridia, Micrhystridium, Veryhachium, Diexallophasis, besides Salopidium granuliferum. Eupoikilofusa, Multiplicisphaeridium, Oppilatala, Visbysphaera, Leiofusa, Helosphaeridium, Cymatiosphaera, Eisenackidium, and Pterospermella are normally present, while chitinozoans and scolecondts are normally present in small numbers.

The common presence of Diexallophasis, Micrhystridium, Leiosphaeridia and Salopidinium granuliferum is also a feature of the Cyrtograptus centrifugus Zone assemblages from Bornholm. Chitinozoans are rare in the Bornholm samples, and they are also rare in the Salopidium granuli- ferum Assemblage of Doring and Bell. In the Welsh Borderlands and Midlands of England, the Salopidium granuliferum Assemblage occurs in bedded argillaceous limestones and calcareous mudstones of the Basement Beds of the Much Wenlock Limestone and the top of the Coalbrookdale Formation. Dorning and Bell (1987) suggested that these assemblages were distributed in deeper open marine shelf environments.

As previously noted, research on the potential use of marine palynomorphs as indicators of $\mathrm{Pa}$ leozoic depositional environments is still at a preliminary stage. In fact, very littel information has become availble during the thirty years since Staplin (1961) presented his pioneering paper on "reef-controlled distribution of Devonian microplankton in Alberta". However, the similarity between the deep water open marine Salopidium granuliferum Assemblage from the Wenlock carbonate shelf in eastern Britain and the assemblages recorded from the Cyrtograptus centrifugus zone on Bornholm is noteworthy.

Acknowledgements. Samples from Bornholm were collected by Jon A. Markussen. Thanks are due to Dr. R.M. Goll for reading and improving the submitted manuscript and to Ellen M. Solberg and Inger Lisbet Berg for typing and drafting, respectively.

\section{Dansk sammendrag}

Palynomorf-floraer med en moderat diversitet af acritarker og prasinohyt alger og med relativt få chitinozoer og miosporer er påvist i skiferprøver fra Cyrtograptus centrifugus graptolit zonen ved Øleå på Bornholm. På grund af høj termisk påvirkning er palynomorfere gennemgående dårlig bevaret. De beskrevne palynomorf-floraer er sammenlignbare med tidlig Wenlock (Sheinwoodian) marine mikrofloraer beskrevet fra andre lokaliteter i Nordvesteuropa og Sovjet, og kendnetegnes ved slægterne Leiosphaeridia, Diexallophasis, Oppilatala, Salopidium og Micrhystridium. Palynomorf-floracrne påvist $\mathbf{i}$ de tidligste Wenlock aflejringer på Bornholm er sammenlignelige med floraer beskrevet af Dorning og Bell (1987) fra åbne marine dybvands aflejringer på "Wenlock Karbonat-soklen" i Welsh Borderland og Midlands i England (dvs. Salopidium granuliferum floraen). Tilstedevarelsen af Domasia elongata og Domasia trispinosa, sammen med ?Deunffia sp. bekræfter at de tidlige Wenlock aflejringer på Bornholm hører til Deunffia-Domansia biofacies som defineret af Cramer $(1970,1971,1971$ a).

\section{References}

Al-Ameri, T. K., 1983: Acid-resistant microfossils used in determination of Paleozoic paleo-environments in Libya. $\mathrm{Pa}$ laeogeogr., Palaeoclimatol., Palaeoecol., 44: 103-116.

Aldridge, R. J., Dorning, K. JH., Hill, P. J., Richardson, J. B. 
and Siviter, D. J., 1979: Microfossil distribution in the Silurian of Britan and Ireland. In: The Caledonides of the British Isles - reviewed. Geological Society of London, 433-438.

Barron, H. F., 1989: Mid-Wenlock acritarchs from a Silurian inlier in the Cheviot Hills, NE England. Scott. J. Geol., 25: 81-98.

Bassett, M. G., Cocks, L. R. H., Holland, C. H., Richards, R. B. and Waron, P. T., 1975: The type Wenlock Series. Institute of Geological Sciences, Report 75/13, 1-19.

Bjerreskov, M., 1971: The stratigraphy of the Llandovery series on Bornholm. Bull. geol. Soc. Denmark, 21: 34-50.

Bjerreskov, M., 1975: Llandoverian and Wenlockian graptolites from Bornholm. Fossil and strata, 8: 1-94.

Buchardt, B. and Nielsen, A. T., 1985: Carbon and oxygen isotope composition of Cambro-Silurian limestone and anthraconite from Bornholm: Evidence for deep burial digenesis. Bull. geol. Soc. Denmark, vol. 33, pp. 415-435.

Cramer, F. H., 1970: Middle Silurian continental movement estimated from phytoplankton-facies transgression. Earth and Planetary Science Letters, 10: 87-93.

Cramer, F. H., 1971: A palynostratigraphic model for Atlantic Pangea during Silurian time. Mémoire du B.R.G.H., 73: 229-235.

Cramer, F. H., 1971a: Implications from Middle Paleozoic palynofacies transgression for the rate of crustal movement, especially during the Wenlockian. An. Acad. brasil Cienc., 43 (supp.): 51-66.

Cramer, F. H. and Diez De Cramer, M.D.C.R., 1972: North American Silurian palynofacies and their spatial arrangement: Acritarchs. Palaeontogical Abt. B., 138: 107-180.

Cramer, F. H. and Diez, M.D.C.R., 1974: Early Paleozoic palynomorphs provinces and paleoclimate. Soc. Eco. PaI. Min. Spec. Publ., 21: 177-188.

Cramer, F. H., Diez, M.D.C.R. and Kjellstrøm, G., 1979: Acritarchs. In: Faunal and Floral dynamics in a Lower Wenlockian sequence - The "Vattenfallet" section of Gotland. Sveriges geol. Unders. ser. C., 762 (73), 39-53.

Dorning, K.J., 1981: Silurian acritarchs from the type Wenlock and Ludlow of Shropshire, England. Rev. Palaeobot. Palynol., 34: 175-203.

Dorning, K. J., 1981a: Silurian chitinonzoa from the type Wenlock and Ludlow of Shropshire, England. Rev. Palaeobot. Palynol., 34: 205-208.

Dorning, K. J., 1981b: Silurian acritarchs distribution in the Ludlovian shelf sea of south Wales and the Welsh Borderland. In: Neale, J. W. \& Braiser, M. D. (eds.). Microfossils from Recent and Fossil shelf seas. Ellis Horwood, Chichester, 31-36.

Dorning, K. J., 1982: Early Wenlock acritarchs from the Knockgardner and Straiton Grit Formations of Knockgardner, Ayrshire. Scott. J. Geol., 18: 267-273.

Dorning, K. J., 1983: Palynology and Stratigraphy of the Much Wenlock Limestone Formation of Dudley, central England. Mercian Geologist, 9: 31-40.

Dorning, K. J. and Bell, D. G., 1987: The Silurian carbonate shelf microflora: acritarch distribution in the Much Wenlock Formation. In: Hart, M. B. (ed.). Micropalaeontology of carbonate environments. Ellis Horwood Ltd., Chichester, 266-287.

Downie, C., 1959: Hystrichospheres from the Silurian Wenlock shale of England. Palaeontology, 2: 56-71.
Downie, C., 1963: Hystrichospheres (Acritarchs) and spores of the Wenlock shales (Silurian). Palaeontology, 6: 625-652.

Downie, C., 1984: Acritarchs in British stratigraphy. Geol. Soc. London, Spec. Rep., 17: 1-26.

Gravesen, P. and Bjerreskov, M., 1984: Outline of the geology of Bornholm. Dann. geol. Unders., ser. C., 3, 2-23.

Gray, J., Boucot, A. J., and Laufeld, S., 1974: Silurian trikte spores and spore tetrades from Gotland. Their Implications for Land Plant Evolution. Science, 185: 260-263.

Hill, P. J., 1974: Stratigraphic palynology of acritarchs from the type area of the Llandovery and the Welsh Borderland. Rev. Palaeobot. Palynol., 18: 11-23.

Kirjanov, V. V., 1087: Akritarchi Silura Volynopodolii. Nankoma Dumka, Kiev. 136 pp.

Klingspor, I., 1976: Radiometric age determinations of basalts, dolerites and related syenite in Skåne, southern Sweden. Geol. Fören. Stockh. Förh., 98, 196-216.

Larsen, B. T., Midtkandal, P. A., Steel, R. and Steinlein, O., 1981: Geology and tectonics of the central Oslofjord, Oslo Rift. News from the Oslo region research Group, 7, 51-79.

Laufeld, S., 1974: Silurian Chitinozoa from Gotland. Fossils and Strata, 5: 1-130.

Mabillard, J. E. and Aldridge, R. J., 1985: Microfossil distribution across the base of the Wenlock series in the type area. Palaeontology, 28, pp. 89-100.

Martin, F., 1968: Les acritarches de l'Ordovicien et du Silurien belges. Détermination et valeur stratigraphique. Mém. Inst. R. Sci. Nat. Belg., 160, 175 pp.

Martin, F., 1974: Ordovicien Supérieur et Silurien Inférieur a Deerlijk (Belgique). Palynofacies et microfacies. Mém. Inst. R. Sci. Nat. Belg., 174, 71 pp.

Priewalder, H., 1987: Acritarchen aus dem Silur des CellonProfils, Karnische Alpen, Österreich. Abh. Geol. Bundesanstalt, 4: 1-121.

Paulsen, V., 1966: Cambro-Silurian stratigraphy of Bornholm. Meddel. Dansk Geol. Foren., 16: 117-137.

Richardson, J. B. and McGregor, D. C., 1986: Silurian and Devonian spore zones of the Old Red Sandstone Continent and Adjacent regions. Geol. Survey Canada, Bull., 364: 1-79.

Sheshegova, L. I., 1975: Fitoplankton Silura Tuvy (razrez "Elegest"). Trudy Inst. Geol. Geofiz. Ota., 224, 99 pp.

Smelror, M., 1987: Early Silurian acritarchs and prasinophycean algae from the Ringerike District, Oslo Region (Norway). Rev. Palaeobot. Palynol., 52, 137-159.

Smelror, M., 1987a: Llandovery and Wenlock miospores and spore-like microfossils from the Ringerike district, Norway. Norsk Geol. Tidsskr., 67: 143-150.

Staplin, F. L., 1961: Reef-contolled distribution of Devonian microplankton in Alberta. Palaeontology, vol. 4, pp. 392424.

Staplin, F. L., 1969: Sedimentary organic matter, organic metamorphism and oil and gas occurrence. Bull. Can. Petrol. Geol., vol. 17, pp. 47-66.

Staplin, F. L., 1977: Interpretation of thermal history from color of particulate organic matter - a review. Palynology, 1: 9-18.

Verniers, J., 1981: The Silurian of the Mehaigue Valley (Brabant Massif, Belgium): Biostratigraphy (Chitinozoa). Rev. Palaeobot. Palynol, 34: 165-174. 